\title{
THE IMPORTANCE OF CUSTOMERS AND EMPLOYEES IN THE MUSLIM-FRIENDLY HOTELS: A REVIEW AND PROPOSED MODEL
}

\author{
Noor Amalina Mat Yusof ${ }^{1}$, Wan Jamaliah Wan Jusoh², Khairusy Syakirin Hasyun Hashim³
}

1 School of Tourism, Hospitality and Event Management (STHEM), Universiti Utara Malaysia, Malaysia. International Institute for Halal Research and Training (INHART).

Email: nooramalina@uum.edu.my

2 Department of Business Administration, International Islamic University Malaysia, Malaysia.

Email: wjamaliah@iium.edu.my

3 International Institute for Halal Research and Training (INHART).

Email: syakirin@iium.edu.my

\section{Article Info:}

\section{Article history:}

Received date:21.10.2019

Revised date: 04.11.2019

Accepted date: 20.01 .2020

Published date: 13.03 .2020

\section{To cite this document:}

Mat Yusof, N. A., Jusoh, W. J. W., \& Hashim, K. S. H. (2020). The Importance of Customers and Employees in The Muslin-friendly Hotels: A Review and Proposed Model. Journal of Tourism, Hospitality and Environment Management, 5 (18), 10-24.

DOI: $10.35631 /$ JTHEM.518002.

\section{Abstract:}

The purpose of this conceptual paper is an attempt to introduce the model which illustrates the internal marketing strategy. It based on a critical review of the literature for insights that integrate internal Muslim-friendly hotels (MFH) and provide customer satisfaction. The review suggests that scholars in the area of Islamic marketing should start working towards the internal environment of $\mathrm{MFH}$, in addition to discussing the importance of customers without looking at the needs of internal MFH. This paper proposes a conceptual framework that involves service climate, service behavior, and customer satisfaction. The dyadic interaction between employees-customers in a service serves as a basis of the conceptual framework development. This paper also suggests a dyadic multilevel method to investigate these relationships.

Keywords:

Muslim-Friendly Hotels, Employee, Customer, Service Climate, Service Behavior, Customer Satisfaction

\section{Introduction}

The Muslim population is widely recognized as the fastest-growing population in the world. Statistically, in 2017, 2.18 million were reported and this number is expected to increase to over 30 percent of the total population in 2030 (Muslimpopulation.com, 2017). These figures illustrate huge potential towards Halal travel and its subsection which is Muslim-friendly hotels. 
The massive development of Halal travel started after the incident 9/11 terrorist attack (Henderson, 2009). Subsequent to this incident, Muslim travelers have shifted their travel destinations where they still can embrace Islam (Dahir, 2017). Thus, their travel preferences including the Organization of Islamic Cooperation (OIC) countries such as Malaysia and nonOIC countries such as Singapore, Japan, and New Zealand (McClain, 2016; Mohsin et al., 2015).

The Muslim demands seemed like great business opportunities to the countries. Along with rapid demands on Halal travel, the subsection of travel which is accommodation is facing a similar development. This type of hotel is known as Muslim-friendly hotels (MFH). MFH is referred to as accommodation that offered a range of facilities in accordance with Islamic religious beliefs to enable Muslim travelers to perform regular religious duties while traveling (Alserhan, 2010; Henderson, 2010; Stephenson, 2014). The enforcement, therefore, must also follow the Islamic principle, by which the Qur'an as a main reference and Sunnah and Fiqh.

All the studies reviewed so far, however, suffer from the fact that securing the internal environment may assist the process of sustaining a Muslim-friendly industry. The recent studies concentrated much on the background of Muslim-friendly concept and ideal features of products and services (Samori, Salleh, \& Khalid, 2015; Stephenson, 2014; Zamani-Farahani \& Henderson, 2010). A recent systematic literature review conducted by Oktadiana, Pearce, and Chon (2016) confirmed that these two issues are the most discussed topics, and also posited other issues are far left behind. The information obtained from the current issues is deemed important in developing Halal travel, but it is inadequate particularly in accomplishing sustainable Halal-hub. In addition, there is no attempt made to quantify the association between the internal environment perceived by the employees and customer experiences.

This paper aims to propose a conceptual framework that can integrate the internal and external environment of MFH. This conceptual framework is proposed based on the relevant previous literature conducted all around the world.

\section{Literature Review}

\section{MFH Background of Malaysia}

Malaysia has taken seriously in dealing with its Halal tourism. Thanks to its familiarity with the Islamic lifestyle, perhaps assist the development of the Halal tourism industry aligned with Muslim tourists' needs and wants (Zailani et al., 2011). The Malaysian government also aggressively supported the Halal industry by establishing relevant agencies to assist the development (HDC, 2013; Idris \& Wahab, 2015). The development can be illustrated by the availability of Halal food and prayer facilities, excellent hospitality services for Muslim tourists, including hotel and tour package, stability and safety, rich Islamic artifacts and also the availability of Islamic financial (Shafaei \& Mohamed, 2017). Besides that, an online accommodation directory such as Tripfez may also assist the development of Halal tourism as Muslim tourists can easily identify, compare and booking MFH according to their preferences (Tripfez, 2018). According to the Global Muslim Travel Index (GMTI), Malaysia is on its leading position for the preferred Muslim-friendly destinations for eight consecutive years.

As mentioned, MFH is a part of Halal tourism may also experience greater development. It emerges to complete the needs and wants of Muslim tourists who looking for accommodation completed with Muslim-friendly services. Suit with MFH definition was offering services with 
specialty to satisfy the needs and wants of Muslim tourists while traveling (Alserhan, 2010; Henderson, 2010; Stephenson, 2014). Similarly, with other service organizations, this MFH also needs employees and customers to sustain in the industry. The details of these two assets further discussed in the next section.

\section{The Importance of Knowing Both Customers and Employees}

The organization, customers and employees are also involved in service encounters. Even though external customers are usually seen as the focal point for service excellence, internal customers who are directly connected to an organization are equally important.

The customers have given special treatment into consideration that they are the primary source of most organizations' revenue (Tam, 2004; Taylor \& Baker, 1994). Customers who are satisfied with products and services induce many positive outcomes for the organization. Many scholars found the positive and significant association between customer satisfaction and postpurchase phenomena, such as profitability (Schneider et al., 2009), revisit intention (Sadeghi et al., 2016), loyalty (Fornell et al., 1996; Hallowell, 1996) and positive word-of-mouth (Shin et al., 2017). Therefore, satisfied customers may assist the organization lead the intense competition and also sustain the industry.

Since MFH special emerged to satisfy Muslim tourist's demands, their main customers are Muslims. Nowadays, Muslim consumers are seemed to be wiser in choosing the products and services. The consumers, especially Muslims were reported to have become more cautious about the quality of MFH (Muhamad \& Mizerski, 2010). It is because some organizations might treat the opportunity as a marketing ploy. Pretending as one of the MFH might assist them to generate more profit (Rosenberg \& Choufany, 2009). For instance, the dry hotels, which are conventional hotels, which often placed on the prohibition of alcohol, but the other operations and services maintain with conventional style (Ridzuan \& Zahari, 2012; Rosenberg \& Choufany, 2009). Besides, reported that Muslim visitors have their own preferences of Muslim-friendly products and services such as reasonable prices of facilities, Muslim-friendly programs, halal food and accommodation with the concept relaxation but luxury. Irfan (2014) added that Muslim consumers are searching for value, quality and proper Islamic practices for their travel destinations and facilities. Another criterion of the Muslim-friendly hospitality establishments includes not only provide facilities which compliance to Islamic principle, but also must not exploit labor and environment (Hanzaee \& Ramezani, 2011).

Employees also have a crucial role in the organization, as well as customers. The employees are argued to serve equally important for the organizations' revenue (Bettencourt \& Brown, 1997; Hong et al., 2013; Schneider et al., 2005). This is because the employees are responsible for delivering and selling products and services on behalf of the organization. They act as the representative for the organization. Their performance has significantly influenced service quality and a satisfactory level of customers (Liao \& Chuang, 2004; Parasuraman et al., 1985; Schneider et al., 2005). It is important for the employees to manage to create a favorable image of the organization (Bettencourt \& Brown, 1997; Schneider \& Bowen, 1993). Therefore, the employees are a valuable asset which the organization must care for as the quality of service delivery mostly depending on them. In addition, whether or not the services better than the competitor rely on their performance.

The discussion on the role of employees related to the MFH has received inadequate attention compared to the customers. Several of the articles may refer to the views of management level regarding the potential of MFH industry (Karim, Ahmad, \& Zainol, 2014; Sahida, Rahman, 
Awang, \& Man, 2011) while most of the articles only view employees' appearance apart from the features of MFH (Henderson, 2010; Rosenberg \& Choufany, 2009; Salleh, Hamid, Hashim, \& Omain, 2014; SIRIM, 2015; Stephenson, 2014). Apart from treating the employees as a tool for MFH, we here assumed that the concept of Muslim-friendly may also reflect the behaviors of the employees. For those MFH which follow guidelines from MS2016:2015 Muslim friendly hospitality services - requirement shall appoint a trained Muslim officer. The job scope of this Muslim officer is to ensure the implementation of MFH (SIRIM, 2015). With the assistance of the Muslim officer, the working environment in MFH may also change in positive ways.

To sustain, the organization of MFH must offer the products and services in line with the Muslim-friendly concept. In the meantime, they must not ignore the importance of employees in the organization as their representative while delivering excellence an experience of the Muslim tourists.

\section{Social Exchange Theory (SET)}

Services are mostly relying upon human interactions. Social interaction with services commonly involves organization, employees and customers. These social interactions can be explained through the Social Exchange Theory (SET).

SET is amongst the most influential conceptual paradigms for understanding workplace behavior. The discussion has stimulated a great deal of academic research since the 1920s (Blau, 1964; Cropanzano \& Mitchell, 2005; Gouldner, 1960; Malinowski, 2002). Within SET, social interactions are seen as mutually dependent, and responses are generated by the actions of the other person in exchange (Blau, 1964). Blau (1964) defined as "voluntary actions of individuals that are motivated by the returns they are expected to bring and typically do in fact bring from others" (Blau, 1964, p. 91). In other words, the quality of service delivered by the employees is encouraged by the extent he/she perceives treatment provided by the organization. Previous studies have investigated various exchanges between employees and their organization or between employees and their supervisors (Auh, Menguc, Fisher, \& Haddad, 2011; Cropanzano \& Mitchell, 2005; Konovsky \& Pugh, 1994; Mechinda \& Patterson, 2011; R. Y. Zhang, Liu, Wang, \& Shen, 2011a). Despite the internal environment, some scholars also found a similar relationship between provider and customers, due to the fact that both of them expect to obtain 'returns' from the relationship (Bettencourt, 1997; Sierra \& McQuitty, 2005).

Quantifying the social interactions inside an organization, employees and customers can be conducted through the service climate concept. Despite this concept has been widely used in diverse service organizations worldwide (Ehrhart et al., 2011; Hui et al., 2007; Schneider et al., 2005; Yagil \& Gal, 2002; Zhang \& Kuminoff, 2010), we used to propose the relationship in MFH organizations. The uniqueness of MFH is believed can attract customers to visit the premises, but also influence employee behaviors. This paper provides an exciting opportunity to advance our knowledge of the internal environment of the premises and how this environment could influence employee and customer behavior.

\section{Service Climate}

The organization must establish and maintain a climate for service to motivate the employees in order to deliver services to the customers (Johnson, 1996). Climate for service, or frequently referred to as service climate acts as the motivating factor for the employees with regard to services. The most cited definition of service climate is 'employees shared perceptions of the practices, procedures, and behaviors that get rewarded, supported, and expected with regard to customer service and customer service quality' (Schneider, White, \& Paul, 1998, p. 151). The 
definition shows that employees are more likely to deliver excellent service in consideration that the organization expects and rewards such behaviors with regard to service quality and supported the process of service delivery (Schneider et al., 1992).

This concept is also known as linkage research where it may link the internal and external environment of the service organization. Dean (2004) stated that this concept used to integrate the various perspectives of marketing, operations, human resources, and psychology in order to support organizations, employees and customers. The examples of service climate variables are training, knowledge, and skills of employees, recognition, and rewards for excellent services, communication, leadership, tools, technology and other resources (Johnson, 1996; Schneider et al., 1998). Much research also found the significant result of a positive service climate towards the employee's performance and customer experiences (Bowen \& Schneider, 2014; Hong et al., 2013).

According to the SET, when employees rate a positive service climate, in return, they will deliver good service to the employees. Consequently, due to the excellent service delivered, the customer will also satisfy. Finally, when the customer satisfies, they will return and spread the good word-of-mouth, which may benefit the organization in the long term.

\section{Service Climate and Its Consequences in The MFH}

The Islamic principle leads to the Islamic ethical business. The main goal of business is based on "Islamic concepts of human wellbeing, which emphasizes on brotherhood/sisterhood and socioeconomic justice and requires a balanced satisfaction of both the material and spiritual needs of all human" (Rice, 1999, p. 346). Therefore, MFH which is regarded as one of the Islamic operating business has a responsibility towards its stakeholders such as their employees, community, and customers. As mentioned, we assumed MFH may also reflect the employees' behaviors by assigning responsibility to the Muslim officer in the operation (SIRIM, 2015). Besides that, operating according to the Al-Quran and Sunnah may help the organization in minimizing unethical cases such as corruption, fraud, sexual harassment and other unethical behaviors (Abdi et al., 2014). Abuznaid (2009) has listed more detailed benefits of having such operation of the business, which is (1) the operation is becoming effective and efficient, (2) lead to integrity, (3) avoid cheating and deceit behaviors, (4) prevent corruption and abuse of power, (5) lead to better responsibility towards the employees, (6) lead to consistent consultation and cooperation in the business, and finally, (7) lead to better quality of business. Here, we can conclude the benefits of MFH is it's really in the Islamic way of the operation.

MFH operates aligned with Islamic guidelines with Al-Quran and Sunnah as the main reference. Here, the model which illustrates the association between the organization, employee and customers.

\section{Service Climate and Customer Satisfaction}

All service organizations desired a higher level of customer satisfaction. Many benefits will be gained if they are able to produce satisfactory customers (Fornell et al., 1996; Sadeghi et al., 2016; Schneider et al., 2009; Shin et al., 2017). It has been proven that customer satisfaction may assist the organization to lead the intense competition and also sustain the industry.

In the west, service climate often related to customer satisfaction. A plethora of research has revealed the positive and significant relationship between service climate and customer satisfaction in various business organizations. In the 1980s, two early studies discovered those 
bank branches where the service policies and practices were described in positive terms by service employees were on the same branches with the service quality that was described in positive terms by customers (Schneider et al., 1980; Schneider \& Bowen, 1985). In other words, customer satisfaction is recorded when employees at the same time satisfied with the organizational service climate. The findings only found in the 1980s, but also in the recent articles. In a longitudinal study conducted by Schneider et al. (2009), service climate was also found to be significant to the customer satisfaction. Other than that, there were replicative findings in another cross-sectional study (Auh et al., 2011; He, Li, \& Keung Lai, 2011; Martinez-Tur, Tordera, Peiró, \& Potocnik, 2011; Towler, Lezotte, \& Burke, 2011).

To date, there are no studies being conducted in revealing the relationship between MFH and customer satisfaction. Some of the studies may focus on customer satisfaction but it is related to the products and services offered by the MFH (Battour, Battor, \& Ismail, 2012; Zulkharnain \& Jamal, 2012). According to the SET theory, satisfied employees will tend to deliver good service, where at the same time the customers who receive the service will also be satisfied.

Hypothesis 1: Service climate is positively related to customer satisfaction in MFH

\section{Service Climate and Employees' Service Behavior}

Employees are important assets of the organization. Thus, the organization must create a conducive environment where can encourage their positive behavior, in this paper, behavior towards delivering excellent service to the customers. Abuznaid (2009) in his study involved Islamic service organizations, found that organization to be amongst the factor which can influence their employees' behavior. By definition, service behavior is referred to as the degree to which employees "concern to satisfy customer requirements and to provide high-quality customer service" to the customers (Peccei \& Rosenthal, 1997, p. 69).

The SET theory may explain the relationship between a strong service climate and an individual or unit of employees' behavior. When employees perceive the organization expects, supports and rewards for quality service (positive service climate), the employees consider their work roles are valued by the organization. Consequently, those employees tend to respond with greater performance as an exchange (Shaw et al., 2009). In other words, employees tend to react with positive behaviors as an exchange for the favorable treatment provided by the organization - SET (Blau, 1964). In the conventional service organization, many research have found the significant and positive relationship between service climate and employees' service climate (Borucki \& Burke, 1999; Drach-Zahavy \& Somech, 2013; Jiang et al., 2016; Kralj \& Solnet, 2010; Liao \& Chuang, 2004; Schneider et al., 2005; Zhang et al., 2011a).

MFH implemented the Islamic principle, therefore, it is assumed that the implementation may also encompass the management. In a study involving an Islamic-related organization in Pakistan, there are four factors that can induce the employees' perception of service quality. These factors may include (1) employees' perception about training and development, (2) development and positioning of Islamic products or services, (3) customer service orientation and (4) employees' service quality performance (Bhatti et al., 2011). All of these factors are amongst the service climate factors as listed by the (Johnson, 1996). Thus, well supports are needed in order to encourage the employees' behavior in delivering excellent service. Here, we also assumed the replicative finding will be found, which may yield the following hypothesis:

Hypothesis 2: Service climate is positively related to service behavior in MFH 


\section{Service Behavior and Customer Satisfaction}

Service employees are responsible for delivering the excellent service in the way as promised by the organization and also creating a favorable image on behalf of the organization (Bettencourt \& Brown, 1997; Schneider \& Bowen, 1993). The service encounter that relies on the service employees' behavior as the representative of the companies may lead to positive or negative customer satisfaction. A study conducted by Amin, Yahya, Ismayatim, Nasharuddin, and Kassim, (2013) which focus on the hotel sector in Malaysia found that staff courtesy and their presentation and knowledge are amongst the five main dimensions which affecting their satisfaction level. In another study by Salleh, Suki and Sondoh Jr (2012) discovered that Islamic-friendly worker is amongst the 10 images which can illustrate the Muslim-friendly image of the organization. This attribute is also assumed to influence customers' perceived satisfaction. In a conventional organization, there are several previous studies that found a positive significant relationship between employees' service behavior and customer satisfaction (Liao \& Chuang, 2004; Schneider et al., 2005).

This study, therefore, proposes a significant positive relationship between service behavior and customer satisfaction.

Hypothesis 3: Service behavior is positively related to customer satisfaction

\section{The Mediating Effect Between Customer Satisfaction, Service Behavior, and Customer Satisfaction}

In the studies of service climate, the service climate has found not directly yield customer experiences, but it affects employee service behavior (Borucki \& Burke, 1999; Bowen \& Schneider, 2014; Liao \& Chuang, 2004; Salanova et al., 2005; Schneider et al., 1998, 2005).

The previous literature acknowledged all the three "preconditions" of the mediator proposed by Baron and Kenny (1986). The literature posited the positive and significant relationship between service climate and customer satisfaction ( Auh et al., 2011; Martinez-Tur et al., 2011; Schneider \& Bowen, 1985; Schneider et al., 2009, 1980, 1998), between service climate and service behavior (Borucki \& Burke, 1999; R. Y. Zhang, Liu, Wang, \& Shen, 2011b) and between service behavior and customer satisfaction (Liao \& Chuang, 2004; Schneider et al., 2005). Particularly, Liao and Chuang (2004) found service behavior as a mediator in the relationship between service climate and customer satisfaction.

So, this study, which involves MFH where implement Muslim-friendly concept also offers the following hypothesis:

H4: Service behavior mediates the relationship between service climate and customer satisfaction in MFH 


\section{Conceptual Framework}

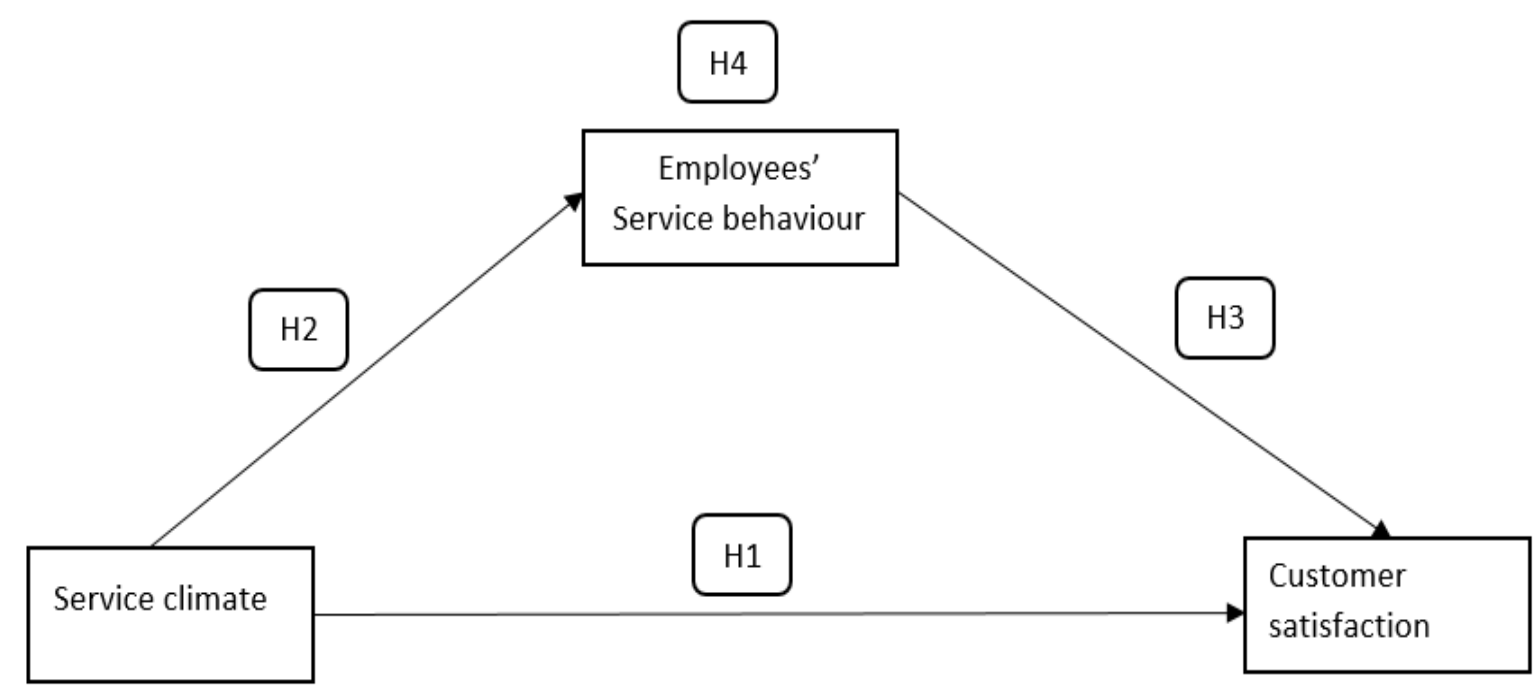

Figure 1: Conceptual Framework

\section{Methodology}

This study will use multilevel data to seek shared perceptions among employees regarding the service climate and to capture the nested complexity of real organization life (Mathieu \& Taylor, 2007). In real organizational life, there are complexities in which employees are depending on the organization that influences their work. It is believed that individual phenomenon is derived from higher-level antecedents such as unit or department or organization (Mathieu \& Taylor, 2007). In this case, an individual employee's behaviors are influenced by the service climate created by the organizations (Mechinda \& Patterson, 2011; Schneider et al., 1998). In fact, the definition of service climate itself is "shared perceptions of employees concerning the practices, procedures and kinds of behaviors that get rewarded and supported in a particular setting" (Schneider et al., 1998) and it shows that this variable is measured by employees perceptions.

The multilevel data for this study associate with two levels; organizational service climate (Level 2) while employee's service behavior and customer satisfaction are individual levels (Level 1). For organizational service climate, to assess data suitability for aggregation, this study will assess evidence by examining them within-group agreement $\left(r_{(w g)}(j)\right.$, James, Demaree, \& Wolf, 1984), intraclass correlation (ICC[1]), reliability of the mean (ICC[2]) and F value from analysis of variance (ANOVA) (Mathieu \& Taylor, 2007). This study will use James et al.'s (1984) agreement index to justify aggregating employee individual members' responses. Median multi-item $\mathrm{r}_{(\mathrm{wg})(\mathrm{j})}$ value $\geq 0.70$ will be generally considered as sufficient agreement to warrant aggregation (Chen et al. (2004) as cited in Mathieu, Maynard, Taylor, Gilson, \& Ruddy, 2007). In addition, the intraclass correlation (ICC) is a variance proportion that is explained by unit level and $\mathrm{F}$ value from ANOVA test must also be significant to suggest that there is sufficient variance for testing such relationship. 
This study emphasizes the interaction of employees-customers in the MFH. The service climate and employee's service behavior questions will be answered by the employees who work at MFH. These employees must be someone who delivers services to customers. While customer satisfaction items will be answered by the customers who stay or visit the MFH at least once.

This study will use the non-probability of the sampling. The samples of $25 \mathrm{MFH}$ organizations with five employees and five customers are preferable. In terms of organizations involved, the number of 25 was adequate to conduct a multilevel study. Even though some scholars argued that 25 organizations are inadequate (Maas \& Hox, 2005; Snijders, 2005). However, a recent study conducted by Mathieu, Aguinis, Culpepper, and Chen (2012) argued organization level (indicating Level 2) is adequate as small as 25 organizations. As such, $25 \mathrm{MFH}$ were indicating an adequate sample to test those four propositions. For employees, work roles included those directly dealing with customers. While, the customers must stay or visited the premises at least once.

The hypotheses testing will be conducted by using Hierarchical Linear Modeling (HLM). While, for the mediation analysis, this study will use a formal test Monte Carlo Method (MCM). This is because Monte Carlo is superior to the Sobel test for multilevel modeling (MacKinnon et al., 2004).

This methodology is chosen due to several reasons. Most halal-related studies in Malaysia mainly used self-report as the basis of the information. The self-report refers to the information obtained only from one side either authorities who involved in Halal related hospitality (Buang \& Mahmod, 2012; Samori \& Abd Rahman, 2013), organizational level (Marzuki, Hall, \& Ballantine, 2014; Sahida et al., 2011) and customers (Abdullah \& Ahmad, 2010; Ahmad, Abaidah, \& Yahya, 2013; Baharudin, Muhamad, \& Mohsin, 2015; Battour et al., 2011). Perhaps the most serious disadvantage of this method is a common method bias (Podsakoff et al., 2003) - in which the respondent tends to answer the question based on his/her illusory. In addition, the self-report approach may not easily be used to pinpoint how internal environment may influence customer satisfaction. This study, however, offers minimization of common method variance/bias as a result from self-reports by considering both internal and external customers of the Muslim-friendly hospitality industry.

\section{Implications}

This paper has some implications for MFH which have to deal with employees while maintaining its excellent services on a daily basis. This proposed article might assist operators in better position their internal environment in line with employees' and customers' needs and wants. In addition, this kind of has not yet tested in relation to Muslim-friendly hospitality, particularly in the Malaysian context. The uniqueness of a Muslim-friendly concept is believed not only enforcing to attract customers but also influence employee behaviors. This study provides an exciting opportunity to advance our knowledge of the internal environment of the premises and how this environment could influence employee and customer behavior.

\section{Conclusion}

In conclusion, this study offers a new angle of research on the relationship between employee and customer may assist MFH's customer satisfaction. Therefore, MFH must treat the employees and customers with a balance. This is because both of them are equally important towards the sustainability of the MFH. The employees are responsible as representative of the MFH and the quality of the services mostly influenced by their behaviors. While customers may help the MFH to gain profit. 


\section{References}

Abdi, M. F., Nor, S. F. D. M., \& Radzi, N. Z. M. (2014). The impact of Islamic work ethics on job performance and organizational commitment. Proceedings of 5th Asia-Pacific Business Research Conference, Kuala Lumpur, Malaysia, 1-12.

Abdullah, K., \& Ahmad, M. I. (2010). Compliance to Islamic marketing practices among businesses in Malaysia. Journal of Islamic Marketing, 1(3), 286-297.

Abuznaid, S. A. (2009). Business ethics in Islam: The glaring gap in practice. International Journal of Islamic and Middle Eastern Finance and Management, 2(4), 278-288.

Ahmad, N. A., Abaidah, T. N., \& Yahya, M. H. A. (2013). A study on halal food awareness among Muslim customers in Klang Valley. The 4th International Conference on Business and Economic Research (4th Icber 2013) Proceeding, 1073-1087. http://www.academia.edu/download/35503039/malay_muslim_awareness_Halal.pdf

Alserhan, B. A. (2010). On Islamic branding: Brands as good deeds. Journal of Islamic Marketing, 1(2), 101-106.

Amin, M., Yahya, Z., Ismayatim, W. F. A., Nasharuddin, S. Z., \& Kassim, E. (2013). Service quality dimension and customer satisfaction: An empirical study in the Malaysian hotel industry. Services Marketing Quarterly, 34(2), 115-125.

Auh, S., Menguc, B., Fisher, M., \& Haddad, A. (2011). The perceived autonomy-perceived service climate relationship: The contingency effect of store-level tenure diversity. Journal of Retailing and Consumer Services, 18(6), 509-520.

Baharudin, M. H. A. M., Muhamad, N. H. N., \& Mohsin, M. A. (2015). Pengurusan Hotel Halal Mengikut Perspektif Islam dan Masyarakat. Sains Humanika, 5(3). http://www.sainshumanika.utm.my/index.php/sainshumanika/article/view/667

Baron, R. M., \& Kenny, D. A. (1986). The moderator-mediator variable distinction in social psychological research: Conceptual, strategic, and statistical considerations. Journal of Personality and Social Psychology, 51(6), 1173.

Battour, Battor, M. M., \& Ismail, M. (2012). The mediating role of tourist satisfaction: A study of Muslim tourists in Malaysia. Journal of Travel \& Tourism Marketing, 29(3), 279297.

Battour, M., Ismail, M. N., \& Battor, M. (2011). The impact of destination attributes on Muslim tourist's choice. International Journal of Tourism Research, 13(6), 527-540.

Bettencourt, L. A. (1997). Customer voluntary performance: Customers as partners in service delivery. Journal of Retailing, 73(3), 383-406.

Bettencourt, L. A., \& Brown, S. W. (1997). Contact employees: Relationships among workplace fairness, job satisfaction and prosocial service behaviors. Journal of Retailing, 73(1), 39-61. https://doi.org/10.1016/S0022-4359(97)90014-2

Bhatti, M. I., Zafarullah, M., Awan, H. M., \& Bukhari, K. S. (2011). Employees' perspective of organizational service quality orientation: Evidence from Islamic banking industry. International Journal of Islamic and Middle Eastern Finance and Management, 4(4), 280-294.

Blau, P. M. (1964). Exchange and power in social life. John Wiley \& Sons.

Borucki, C. C., \& Burke, M. J. (1999). An examination of service-related antecedents to retail store performance. Journal of Organizational Behavior, 943-962.

Bowen, D. E., \& Schneider, B. (2014). A service climate synthesis and future research agenda. Journal of Service Research, 17(1), 5-22.

Buang, A. H., \& Mahmod, Z. (2012). Isu dan cabaran badan pensijilan halal di Malaysia. Jurnal Syariah, 20(3), 275.

Cropanzano, R., \& Mitchell, M. S. (2005). Social exchange theory: An interdisciplinary review. Journal of Management, 31(6), 874-900. 
Dahir, A. L. (2017). The new growth industry in Africa is Muslim tourism. Quartz Africa. https://qz.com/964280/africa-looks-to-cash-in-on-the-global-appetite-for-halaltourism/

Dean, A. M. (2004). Links between organisational and customer variables in service delivery: Evidence, contradictions and challenges. International Journal of Service Industry Management, 15(4), 332-350. https://doi.org/10.1108/09564230410552031

Drach-Zahavy, A., \& Somech, A. (2013). Linking task and goal interdependence to quality service: The role of the service climate. Journal of Service Management, 24(2), 151169.

Ehrhart, K. H., Witt, L. A., Schneider, B., \& Perry, S. J. (2011). Service employees give as they get: Internal service as a moderator of the service climate-service outcomes link. Journal of Applied Psychology, 96(2), 423.

Fornell, C., Johnson, M. D., Anderson, E. W., Cha, J., \& Bryant, B. E. (1996). The American customer satisfaction index: Nature, purpose, and findings. The Journal of Marketing, $7-18$.

Gouldner, A. W. (1960). The norm of reciprocity: A preliminary statement. American Sociological Review, 161-178.

Hallowell, R. (1996). The relationships of customer satisfaction, customer loyalty, and profitability: An empirical study. International Journal of Service Industry Management, 7(4), 27-42.

Hanzaee, K. H., \& Ramezani, M. R. (2011). Intention to halal products in the world markets. Interdisciplinary Journal of Research in Business, 1(5), 1-7.

HDC. (2013). Halal Agencies in Malaysia. Halal Industry Development Corporation. http://www.hdcglobal.com/publisher/bhi_halal_agencies

He, Y., Li, W., \& Keung Lai, K. (2011). Service climate, employee commitment and customer satisfaction: Evidence from the hospitality industry in China. International Journal of Contemporary Hospitality Management, 23(5), 592-607.

Henderson, J. C. (2010). Sharia-compliant hotels. Tourism and Hospitality Research, 246-254.

Hong, Y., Liao, H., Hu, J., \& Jiang, K. (2013). Missing link in the service profit chain: A metaanalytic review of the antecedents, consequences, and moderators of service climate. Journal of Applied Psychology, 98(2), 237.

Hui, C. H., Chiu, W. C., Yu, P. L., Cheng, K., \& Tse, H. H. (2007). The effects of service climate and the effective leadership behaviour of supervisors on frontline employee service quality: A multi-level analysis. Journal of Occupational and Organizational Psychology, 80(1), 151-172.

Idris, J., \& Wahab, N. A. (2015). The Competitive Advantages of Sharia-Compliant Hotel Concept in Malaysia: SWOT Analysis. http://www.academia.edu/download/43610031/ICOMM_2015_THE_COMPETITIV E_ADVANTAGES_OF_SHARIACOMPLIANT_HOTEL_CONCEPT_IN_MALAYSIA.pdf

Irfan, M. (2014). Muslim buying power. The Muslim Observer. http://muslimobserver.com/muslim-buying-power-new-consumer-survey-highlightsmuslim-american-spending-power-increased-demand-for-ethical-islamic-goods/

James, L. R., Demaree, R. G., \& Wolf, G. (1984). Estimating within-group interrater reliability with and without response bias. Journal of Applied Psychology, 69(1), 85.

Jiang, K., Hu, J., Hong, Y., Liao, H., \& Liu, S. (2016). Do it well and do it right: The impact of service climate and ethical climate on business performance and the boundary conditions. Journal of Applied Psychology, 101(11), 1553.

Johnson, J. W. (1996). Linking employee perceptions of service climate to customer satisfaction. Personnel Psychology, 49(4), 831-851. 
Karim, M. H. A., Ahmad, R., \& Zainol, N. (2014). Hotel managers' intention towards implement Islamic quality standard for hotels in Malaysia: A conceptual paper. http://repo.uum.edu.my/13336/

Konovsky, M. A., \& Pugh, S. D. (1994). Citizenship behavior and social exchange. Academy of Management Journal, 37(3), 656-669.

Kralj, A., \& Solnet, D. (2010). Service climate and customer satisfaction in a casino hotel: An exploratory case study. International Journal of Hospitality Management, 29(4), 711719.

Liao, H., \& Chuang, A. (2004). A multilevel investigation of factors influencing employee service performance and customer outcomes. Academy of Management Journal, 47(1), $41-58$.

Maas, C. J., \& Hox, J. J. (2005). Sufficient sample sizes for multilevel modeling. Methodology, 1(3), 86-92.

MacKinnon, D. P., Lockwood, C. M., \& Williams, J. (2004). Confidence limits for the indirect effect: Distribution of the product and resampling methods. Multivariate Behavioral Research, 39(1), 99-128.

Malinowski, B. (2002). Argonauts of the Western Pacific: An account of native enterprise and adventure in the archipelagoes of Melanesian New Guinea. Routledge.

Martinez-Tur, V., Tordera, N., Peiró, J. M., \& Potocnik, K. (2011). Linking Service Climate and Disconfirmation of Expectations as Predictors of Customer Satisfaction: A CrossLevel Study1. Journal of Applied Social Psychology, 41(5), 1189-1213.

Marzuki, S. Z. S., Hall, C. M., \& Ballantine, P. W. (2014). Measurement of restaurant manager expectations toward halal certification using factor and cluster analysis. ProcediaSocial and Behavioral Sciences, 121, 291-303.

Mathieu, J. E., Aguinis, H., Culpepper, S. A., \& Chen, G. (2012). Understanding and estimating the power to detect cross-level interaction effects in multilevel modeling. Journal of Applied Psychology, 97(5), 951.

Mathieu, J. E., Maynard, M. T., Taylor, S. R., Gilson, L. L., \& Ruddy, T. M. (2007). An examination of the effects of organizational district and team contexts on team processes and performance: A meso-mediational model. Journal of Organizational Behavior, 28(7), 891-910.

Mathieu, J. E., \& Taylor, S. R. (2007). A framework for testing meso-mediational relationships in Organizational Behavior. Journal of Organizational Behavior, 28(2), 141-172.

McClain, J. (2016). Halal travel: Malaysia ranked the most Muslim Friendly destinations. Tourism Review News. https://www.tourism-review.com/best-halal-traveldestinations-news4992

Mechinda, P., \& Patterson, P. G. (2011). The impact of service climate and service provider personality on employees' customer-oriented behavior in a high-contact setting. Journal of Services Marketing, 25(2), 101-113.

Mohsin, A., Ramli, N., \& Alkhulayfi, B. A. (2015). Halal tourism: Emerging opportunities. Tourism

\section{Management}

Perspectives. http://www.sciencedirect.com/science/article/pii/S2211973615001002

Muhamad, N., \& Mizerski, D. (2010). The constructs mediating religions' influence on buyers and consumers. Journal of Islamic Marketing, 1(2), 124-135.

Muslimpopulation.com. (2017). Muslim population by percentage (\%). Muslim Population. http://www.muslimpopulation.com/

Oktadiana, H., Pearce, P. L., \& Chon, K. (2016). Muslim travellers' needs: What don't we know? Tourism Management Perspectives, 20, 124-130.

Parasuraman, A., Zeithaml, V. A., \& Berry, L. L. (1985). A conceptual model of service quality and its implications for future research. The Journal of Marketing, 41-50. 
Peccei, R., \& Rosenthal, P. (1997). The antecedents of employee commitment to customer service: Evidence from a UK. International Journal of Human Resource Management, 8(1), 66-86.

Podsakoff, P. M., MacKenzie, S. B., Lee, J.-Y., \& Podsakoff, N. P. (2003). Common method biases in behavioral research: A critical review of the literature and recommended remedies. Journal of Applied Psychology, 88(5), 879.

Rice, G. (1999). Islamic ethics and the implications for business. Journal of Business Ethics, $18(4), 345-358$.

Ridzuan, A. H. A., \& Zahari, M. S. M. (2012). Dry hotel and Syariah compliant practices: Concepts, challenges and reality in Malaysia. Innovation Management and Technology Research (ICIMTR), 2012 International Conference On, 107-111.

Rosenberg, P., \& Choufany, H. M. (2009). Spiritual lodging-The Sharia-compliant hotel concept. HVS Global Hospitality Services-Dubai. http://www.hvs.com/content/2856.pdf

Sadeghi, M., Zandieh, D., Mohammadi, M., Yaghoubibijarboneh, B., \& Nasrolahi Vosta, S. (2016). Investigating the impact of service climate on intention to revisit a hotel: The mediating role of perceived service quality and relationship quality. International Journal of Management Science and Engineering Management, 12(1), 12-20.

Sahida, W., Rahman, S. A., Awang, K., \& Man, Y. C. (2011). The implementation of shariah compliance concept hotel: De Palma Hotel Ampang, Malaysia. 2nd International Conference Humanities, Historical and Social Sciences, Singapore. http://citeseerx.ist.psu.edu/viewdoc/download?doi=10.1.1.464.2765\&rep=rep1\&type= pdf

Salanova, M., Agut, S., \& Peiró, J. M. (2005). Linking organizational resources and work engagement to employee performance and customer loyalty: The mediation of service climate. Journal of Applied Psychology, 90(6), 1217.

Salleh, A. S. A., Suki, N. M., \& Sondoh Jr, S. L. (2012). Attributes in Halal Standard: What is in the Mind of Consumers? 1-15.

Salleh, N. Z. M., Hamid, A. B. A., Hashim, N. H., \& Omain, S. Z. (2014). The Practice of Shariah-Compliant Hotel in Malaysia. International Journal of Trade, Economics and Finance, 5(1), 26.

Samori, Z., \& Rahman, F. R. (2013). Establishing Shariah Compliant Hotels in Malaysia: Identifying Opportunities, Exploring Challenges. West East Journal of Social Science, 2(2), 95-108.

Samori, Z., Salleh, N. Z. M., \& Khalid, M. M. (2015). Current trends on Halal tourism: Cases on selected Asian countries. Tourism Management Perspectives, 19, 131-136.

Schneider, B., \& Bowen, D. E. (1985). Employee and customer perceptions of service in banks: Replication and extension. Journal of Applied Psychology, 70(3), 423.

Schneider, B., \& Bowen, D. E. (1993). The service organization: Human resources management is crucial. Organizational Dynamics, 21(4), 39-52.

Schneider, B., Ehrhart, M. G., Mayer, D. M., Saltz, J. L., \& Niles-Jolly, K. (2005). Understanding organization-customer links in service settings. Academy of Management Journal, 48(6), 1017-1032.

Schneider, B., Macey, W. H., Lee, W. C., \& Young, S. A. (2009). Organizational service climate drivers of the American Customer Satisfaction Index (ACSI) and financial and market performance. Journal of Service Research, 12(1), 3-14.

Schneider, B., Parkington, J. J., \& Buxton, V. M. (1980). Employee and customer perceptions of service in banks. Administrative Science Quarterly, 252-267.

Schneider, B., Wheeler, J. K., \& Cox, J. F. (1992). A passion for service: Using content analysis to explicate service climate themes. Journal of Applied Psychology, 77(5), 705. 
Schneider, B., White, S. S., \& Paul, M. C. (1998). Linking service climate and customer perceptions of service quality: Tests of a causal model. Journal of Applied Psychology, $83(2), 150$.

Shafaei, F., \& Mohamed, B. (2017). Malaysia's branding as an Islamic tourism hub: An assessment. Geografia-Malaysian Journal of Society and Space, 11(1).

Shaw, J. D., Dineen, B. R., Fang, R., \& Vellella, R. F. (2009). Employee-organization exchange relationships, HRM practices, and quit rates of good and poor performers. Academy of Management Journal, 52(5), 1016-1033.

Shin, Y., Thai, V. V., Grewal, D., \& Kim, Y. (2017). Do corporate sustainable management activities improve customer satisfaction, word of mouth intention and repurchase intention? Empirical evidence from the shipping industry. The International Journal of Logistics Management, 28(2), 555-570.

Sierra, J. J., \& McQuitty, S. (2005). Service providers and customers: Social exchange theory and service loyalty. Journal of Services Marketing, 19(6), 392-400.

SIRIM. (2015). MS2610:2015 Muslim friendly hospitality services- requirements. Department of Standards Malaysia, 1-20.

Snijders, T. A. (2005). Power and sample size in multilevel modeling. Encyclopedia of Statistics in Behavioral Science, 3, 1570-1573.

Stephenson, M. L. (2014). Deciphering 'Islamic hospitality': Developments, challenges and opportunities. Tourism Management, 40, 155-164.

Tam, J. L. (2004). Customer satisfaction, service quality and perceived value: An integrative model. Journal of Marketing Management, 20(7-8), 897-917.

Taylor, S. A., \& Baker, T. L. (1994). An assessment of the relationship between service quality and customer satisfaction in the formation of consumers' purchase intentions. Journal of Retailing, 70(2), 163-178.

Towler, A., Lezotte, D. V., \& Burke, M. J. (2011). The service climate-firm performance chain: The role of customer retention. Human Resource Management, 50(3), 391-406.

Tripfez. (2018). Enjoy mindful journey: Book a Muslim-friendly hotel for your next trip. Tripfez. https://www.tripfez.com/

Weaver, G. R., \& Agle, B. R. (2002). Religiosity and ethical behavior in organizations: A symbolic interactionist perspective. Academy of Management Review, 27(1), 77-97.

Yagil, D., \& Gal, I. (2002). The role of organizational service climate in generating control and empowerment among workers and customers. Journal of Retailing and Consumer Services, 9(4), 215-226.

Zailani, S., Omar, A., \& Kopong, S. (2011). An Exploratory Study on the Factors Influencing the Non-Compliance to Halal among Hoteliers in Malaysia. International Business Management, 5(1), 1-12.

Zamani-Farahani, H., \& Henderson, J. C. (2010). Islamic tourism and managing tourism development in Islamic societies: The cases of Iran and Saudi Arabia. International Journal of Tourism Research, 12(1), 79-89.

Zhang, C., \& Kuminoff, N. V. (2010). Are travelers willing to pay a premium to stay at a "Green" hotel? Agricultural and Resource Economics Review, 39(3), 468-484.

Zhang, R. Y., Liu, X. M., Wang, H. Z., \& Shen, L. (2011a). Service climate and employee service performance: Exploring the moderating role of job stress and organizational identification. The Service Industries Journal, 31(14), 2355-2372.

Zhang, R. Y., Liu, X. M., Wang, H. Z., \& Shen, L. (2011b). Service climate and employee service performance: Exploring the moderating role of job stress and organizational identification. The Service Industries Journal, 31(14), 2355-2372. 
Zulkharnain, A., \& Jamal, S. A. (2012). Muslim guest perception of value towards Syariah concept hotel. Current Issues in Hospitality and Tourism: Research and Innovations, 337. 